\title{
PARENETIC PRINCIPLES IN THE HOMILETIC WORK OF THE METROPOLITAN BISHOP FIRMILIAN MARIN
}

\author{
Ph.D. Nicușor BELDIMAN \\ Faculty of Orthodox Theology, \\ "Justinian Patriarch", University of Bucharest, \\ ROMANIA, \\ E-mail: prnbeldiman@gmail.com
}

\begin{abstract}
The history of Romanian homiletics knows figures of enlightened hierarchs and scholars, fully aware of the importance of preaching and educating the faithful, homilists who contributed through their sermons to the perpetuation and preservation of the Orthodox faith. A figure of diligent hierarch and zealous preacher, with a significant contribution to the development of Romanian homiletic literature in the second half of the 20th century, was Metropolitan Firmilian Marin of Oltenia, whose life and works provide an exemplary pastoral paradigm, worthy of our attention and deep gratitude. This paper aims to present and investigate the homiletic activity conducted by Metropolitan Firmilian, who holds a prominent place among the great hierarchs of the Romanian Orthodox Church and the Romanian nation: a worthy servant of Christ, a founder of holy churches and places of worship, a great scholar, a supporter of culture and arts and a father of the suffering and needy people. We also aim to provide a model to contemporary preachers, animated by missionary zeal, according to the example set by the diligent hierarch of Oltenia in his times and historical, social, economic and political circumstances.To make his homiletic creation more accessible, we do not merely provide a bio-bibliography and an overview of his sermons, but we also undertake a critical examination of his speeches, in order to present the genres employed, the homiletic technique, the style, originality and coherence of language, with examples that are highly useful to today's preachers.
\end{abstract}

Keywords: Metropolitan Firmilian Marin; pastoral addresses; themes; stylistic devices; homiletic genres;

\section{PRELIMINARY FACTS}

The sermons delivered in the Romanian Orthodox Church of the $20^{\text {th }}$ century reflect the cultural, social, economic and political realities of our nation to a greater extent than those before them. The preaching activity was cultivated to a greater degree in Transylvania, mostly due to the vicinity of the Protestant Church where, as it is known, liturgical simplifications allowed the sermon to take a central position; there was actually a missionary competition going on and it produced well-prepared sermons delivered in the church and published in the time's magazines as well as published in volumes of sermons. However, it is an undeniable fact that in all the other provinces there were equally hard-working preachers who structured their discourses to pursue mainly the religious and moral purpose while also turning their attention to the realities of everyday life. From this perspective, the sermon in the $20^{\text {th }}$ century Romanian Orthodox Church knows three stages: from the beginnings to the installation of the communist regime (1945); the actual communism period 
(1945-1989) and the period in which freedom of speech was regained and fully exercised: 1990-2000. It is a well-known fact, yet ignored by the opponents of righteous faith, that during the communist regime, the Romanian altar was not abandoned, as the leaders of the time would have wanted. Preaching was still going on, at all times, and sometimes under very harsh circumstances ${ }^{1}$. The Church was forced to manifest itself particularly as a cult or by celebrating liturgies in worship places or the Christians' homes, without being able to carry out any organized preaching of the word of God and without the right to defend Christian faith against the attacks, disparagements and lies promoted in the fundamental books of the atheist propaganda. For this reason, we cannot speak of any organized and efficient preaching, because, whenever such type of preaching was initiated, action was immediately taken to stop it. Thus, the communist oppression left deep marks in the preaching activity of the Church. Aside from the social and material deprivations, this was the sector in which the clergy received the most powerful blows.

The great preachers who exercised a powerful influence on the crowds were arrested; prominent intellectuals in all fields of activity were cruelly persecuted. The method of intimidation was applied quite overtly on the crowds in towns and villages: during a sermon, a man dressed casually, in civilian clothes would place himself so that he would be clearly noticed by the priest and, taking out a notebook and a pencil from his pocket, he would make notes as if he were interested in learning and retaining something ${ }^{2}$. Formally, the sermon was not prohibited, but its complete annihilation was actually envisaged. However, the Romanian Orthodox Church, through its survival strategy, did not neglect its teaching role, in spite of these threats, being the only institution that managed to save the nation from a spiritual catastrophe. Thus, the discourses focused solely on the theological aspect, avoiding the comments regarding the social, economic and political situation.

Therefore, the history of the Romanian sermon includes enlightened figures of bishops and erudite priests who, aware of the importance of the clerical preaching activity and the enlightenment of the Christians, contributed through their homiletic writings to the preservation of the heritage of Orthodox faith. A diligent hierarch and preacher, who contributed to the development of the Romanian homiletic literature during the late $20^{\text {th }}$ century was the Metropolitan Firmilian Marin of Oltenia, whose life and work, forming a harmonious pastoral paradigm, is worthy of our attention and gratitude. This study aims to present and examine the homiletic activity of Metropolitan Firmilian, who holds a prominent place among the great hierarchs of the Romanian Orthodox Church and of the Romanian nation, a worthy man in the service of Christ, a founder of places of worship and churches, a scholar, supporter of culture and arts and a father for those afflicted by suffering and poverty; at the same time, we aim to offer a paradigm for a contemporary preaching animated by missionary zeal, as that of the diligent hierarch of Oltenia in the historical, social, economic and political circumstances of those times.

To make his homiletic work more accessible we will address this presentation not only by browsing through the collection of his homilies, but also by attempting to undertake a critical analysis of the discourses subject to our examination, so that we can derive a clear picture of the genres used, of the homiletic technique, of the style, originality and coherence of the language, with examples that will prove particularly useful to today's preachers.

\footnotetext{
${ }^{1}$ Pr. prof. dr. Vasile Gordon, Introducere în Omiletică (Introduction to Homiletics), Publishing House of the University of Bucharest, Bucharest, 2001, p. 119

${ }^{2}$ Metrop. Bishop Bartolomeu Anania, "Cuvânt înainte" ("Foreword") to Lect. dr. Ioan Toader, Metode noi în practica omiletică(New methods in the homiletic practice), Arhidiecezana, Cluj, 1997, p. 4
} 


\section{How the work of Metropolitan Firmilian is perceived by the specialized literature}

Metropolitan Firmilian stood out due to his erudition and oratorical prowess. The priests and Christians who had the opportunity to listen to him, still remember his scholarly knowledge, the beauty of his sermons and the love conveyed by them. We too, can verify today that this is true, just by reading his sermons and pastoral letters. Referring to the homiletic contribution of the Metropolitan Bishop Fimilian, we cannot overlook the books, studies and articles that relate to this fact. As mentioned before, Bishop Firmilan preached the word not only from the altar, but also in written form, most of his sermons being published in Albina and Cuvântul newspapers. A person who noted the beauty of these writings belonging to the Oltenian hierarch was the Metropolitan Bartolomeu Anania, who, in the foreword of the sermon volume entitled Merinde pentru suflet (Food for the soul) states the following: "In my opinion these pages by Firmilan should have been collected in a volume and made available to the readers not only for their literary beauty but also for their topicality. The lights and shadows of the Romanian society from those times still endure today. This makes it all the more necessary to bring back among us the eye that perceives them and the quill that awakens our conscience",3.

The interest in the spirit and work of the Metropolitan increased especially among the professors of theology who, fascinated by his personality, produced several studies for those interested in finding out more about the exemplary activity of the hierarch. In this respect we mention the study by Prof. Adrian Ivan, Ph.D., published in a volume dedicated to the Metropolitans Firmilian Marin and Nestor Vornicescu. It depicts the hierarch not only as one who preached the word but also as one who lived it: "the writing of Metropolitan Bishop Firmilian is straightforward and uncompromising, seemingly derived from the thinking of those great people who had lived in the desert. The ability of a shepherd of the souls is noticeable when he succeeds in correcting those who had wronged others not by sword or bloodshed, nor by reprimand or humiliation which could cause the listeners to become defensive, but by love born from the understanding of the souls of his spiritual children. Like a true father, he would heed the spiritual needs of the simple people, especially of those who came forward after having shown carelessness towards the spiritual matters, wherein lies the cause for losing one's way"4.

As one who showed particular interest in the activity of Metropolitan Firmilian, rev. prof. Sebastian Chilea describes the hierarch as a prominent servant of the altar: "The way in which the High Hierarch celebrated the holy liturgy - peaceful, calm, serene, detached from his surroundings, with his face enlightened by some happy thought, as if he were hearing a call from afar, from a place where there are signs of miracles above any reasoning, proves that this solar peacefulness comes after all storms have calmed down. When his Holiness appears for the liturgy, everybody knows who he is: extremely attentive, kind, showing such warm politeness under which he carefully conceals his authority. But as soon as the preparations for the holy liturgy begin, everything changes, he moves as if standing still, fascinated by a vision. He is silent. He accepts no error or omission and is immediately

\footnotetext{
${ }^{3}$ Mitrop. Bartolomeu Anania, "Prefață" ("Foreword"), in Firmilian Marin, Merinde pentru suflet (Food for the soul), Publishing House of the Metropolitan Bishopric of Oltenia, Craiova, 2004, p. 9

${ }^{4}$ Pr. lect. dr. Adrian Ivan, "Considerații omiletice asupra vieții și activității mitropoliților Firmilian Marin și Nestor Vornicescu" ("Homiletic considerations on the life and activity of the metropolitan bishops Firmilian Marin and Nestor Vornicescu”), in the volume Teologie și slujire pastorală în viața și opera mitropoliților Firmilian Marin și Nestor Vornicescu (Theology and pastoral service in the life and work of metropolitan bishops Firmilian Marin and Nestor Vornicescu), Publishing House of the Metropolitan Bishopric of Oltenia /Craiova, Editura Cetatea de Scaun/Târgoviște, 2014, p. 178
} 
moved when a servant has performed an inspired liturgical act, with talent and artfulness. When slowly putting on his liturgical attire he seems a peaceful traveler getting ready for a significant journey. A journey that is unlike the others, and in which he becomes engrossed. When he stands alone in the middle of the church, before entering the altar, at that very moment shadows barely perceptible fall on his face. It seems as if a great burden is left upon his shoulders, the burden of the Church in the world, a terrible responsibility like that of the pilot of a spaceship setting off on a daunting and bold spiritual expedition, closely watched by those around" .

In addition, Priest M. Neamțu extracts from the hierarch's speeches teachings and advice that are useful to any Christian. He is described as a preacher who understood the needs and suffering of people and advocated through word and deed for their solutions. With the diversity of the topics addressed in his sermons, the Metropolitan acquires the role of a spiritual confessor who attempts to fulfill the needs of the Christians he shepherds: "The personality as dutiful preacher of His Eminence Firmilian, who, like a burning candle, cast his light upon the Christians through his discourses, is confirmed by his work as a social apostle, an arduous and tireless patriot and a fighter for the nation's ideal of a better life, embracing, in his preaching, all the vital issues of the times, such as: peace, disarmament, work for the benefit of the community, well-being and progress, culture, the problems of mother and child, congresses, conferences on peach and cohabitation, and many more. There was no issue of crucial importance, either internally or internationally, on which His Eminence did not take position and speak out His mind"6. Moreover, rev. M. Neamțu in his study also presented the spiritual origins of the word preached by Bishop Firmilian, among which we mention love, unshaken faith, prayer etc.

From the considerations presented by those who studied the life and work of Metropolitan Firmilian, we understand that the voice of this great Church hierarch was heard in the past and continued to be heard at present. The desire to bring his speeches to attention once more, generates in us the belief that our enterprise will reveal in their contents the values that today are proudly proclaimed.

\section{The Structure of his speeches.}

For a discourse to be successful, the preacher needs to be aware that the beautiful and compelling sermons of the great preachers were not produced accidentally, but rather, they are the result of an exceptional effort made in the theological, cultural, pastoral and spiritual realms. While some gifts may be innate, such as physical beauty, the quality of being a skilled speaker entails huge efforts over a significant number of years. The famous Latin orator Cicero is so right in this respect when he says: "Poeta nascitur, orator fit" concisely express the fact that the gift of oratory is not inborn, but it is cultivated ${ }^{8}$. The words of Father Dumitru Belu, the most prolific author of Romanian homiletic studies are extremely convincing in this respect: "it is well-known that a sermon has the value of the

\footnotetext{
${ }^{5}$ Pr. dr. Sebastian Chilea, “Apostolatul liturgic al Î.P.S. Firmilian“ ("Liturgical Apostolate of His Eminence Firmilian”), in Mitropolia Olteniei 5-8 (1970), p. 362

${ }^{6}$ Pr. M. Neamțu, "Activitatea de propovăduitor a Î.P.S. Mitropolit Firmilian" ("The preaching activity of His Eminence Firmilian"), in Mitropolia Olteniei 5-8 (1970), p. 377

${ }^{7}$ Dicţionar de proverbe şi cugetări latine (Dictionary of Latin proverbs and sayings), Albatros Publishing House, Bucharest, 1976, p.165

8 Pr. prof. dr. Vasile Gordon, "Poeta nascitur, orator fit. Vocaţia omiletică a Mitropolitului Antonie Plămădeală" ("Homiletic Calling of the Metropolitan Bishop Antonie Plamadeala"), in Studii Teologice 4 (2005), p. 44
} 
painstaking labor you put into its making" "9. The sermon is a dialogue, not a monologue, and so its success depends greatly on the life and education of the preacher, being the fruit of an incessant effort to improve oneself ${ }^{10}$. If the man who has innate qualities for eloquence needs to study permanently in order to cultivate this gift ${ }^{11}$, then even more so a regular preacher needs to read much, reflect much, using the Holy Scripture as the text that is to be discussed and explained as a departure point, in brief he must prepare thoroughly in order to put together the words of teaching. Referring to this preparation, the Homiletic treaties distinguish among two main stages in the preparation and compiling of a sermon: distant or general and proximal or special. When speaking about proximal preparation, it is essential to point out the fact that the ideas which we have chosen and which we shall develop in the contents of our sermon cannot be presented just anyhow, arbitrarily, but rather by following a pre-established plan. Order is required in all fields of activity and therefore in preaching too. The priest must also work according to a plan. He has the obligation to plan his preaching activity over a longer period of time and devise a precise plan for each of his speeches. The main parts of a plan are: the title (or the "motto"), the addressing formula, the introduction, the actual text and the closing.

Referring to the advantages of using a plan, we would like to highlight the following: eliminating the risk of incongruous ideas, which aids the preacher to follow the intended direction; it leads to a proper selection of the material, gathered as result of the research work; it indicates the order of the ideas to be developed; it offers the speaker a feeling of security; it efficiently helps in memorizing and freely delivering the speech, making it possible for the preacher to acquire an overall perspective throughout the entire sermon, and to develop the ideas in the order indicated by their intrinsic, logical connection ${ }^{12}$. By referring to the importance of preaching according to a plan, we do not mean that in any speech we must announce each point, each idea, they will merely be suggested, with pauses lasting just a few seconds, accompanied, most of the times by the reiteration of the addressing formula ${ }^{13}$. Further on we shall explain how these requisites were observed in the work of Metropolitan Firmilian.

In terms of the structure of his speeches, Firmilian proved to be a subtle oratorical character. He uses almost every opportunity to say a few words that turn into discourses of a person keen on special scholarly preoccupations. All his pastoral letters use, by way of introduction, the following formula: „Firmilian, by God's mercy, Archbishop of Craiova and Metropolitan Bishop of Oltenia, to our beloved clergy, monastic order and to our Christian righteous believers in this God-protected Archbishopric, may the peace and grace of the Resurrected Lord be upon you, and from our humble self, fatherly blessings". Before the addressing formula, which takes on several variations, some speeches are preceded by a motto. This is usually selected from the Bible, either the Old Testament or more frequently from the New Testament, depending on the topic addressed by the contents. As a greeting formula, he uses the traditional "Christ is Risen!", but not in all pastoral letters. Each time he engages the audience and the reader by using addressing formulas according to the event on which he is called to speak. They are expressed in warm, paternal tones: "My beloved sons

\footnotetext{
${ }^{9}$ Pr. prof. dr. Dumitru Belu, Curs de Omiletică (A course in Homiletics), dactil., f.a., Sibiu, p.159

${ }^{10}$ Pr. dr. Nicușor Beldiman, Slujirea omiletică a mitropolitului Firmilian Marin (Homiletic Ministry of the Metropolitan Bishop Firmilian Marin), Publishing House of the University of Bucharest, 2017, p. 29

11 Pr. asist. drd. Vasile Creţu, "Comunicarea în predică" ("Communication in sermons"), in Ortodoxia 3-4 (2004), p. 196

${ }^{12}$ Pr. asist. drd. Vasile Crețu, "Comunicarea în predică" ("Communication in sermons"), p. 152

${ }^{13}$ Pr. prof. dr. Vasile Gordon, Introducere (Introduction), p. 289
} 
of my soul", "Beloved Christians", "You righteous Christian believers", "My beloved spiritual sons", "Oh man, brother of mine", "Brother of mine and fellow man" etc., proving that there is a strong spiritual bond between the shepherd and the Christians. They are then found in all the explanations and urges contained in the speeches, revealing the love he puts in his efforts to enlighten those he shepherds. Moreover: the joys and misfortunes of his spiritual sons are felt by the author who reacts with empathy for and together with them, such empathy being his ability to recognize and share the feelings experienced by another person.

The Introduction is brief in all discourses and is meant to create the atmosphere of the event the author refers to. These are genuine literary works ${ }^{14}$ that touch and overwhelm the listener: "In the icons of the Eastern Church and in the hidden chamber of the Christian soul, the Lord's Nativity has remained forever live and fresh, like a water spring from the land of our redemption. We know the all-pure story from the Gospel, made up of simple words and warmth of speech, as is the truth and as the clear shining of sunlight. The spirit of innocence pervades the story and gently brings us the sweetness of peace, when we listen to it or read it in privacy. We descend back to the world of our infancy, where God's footsteps are heard and we listen to mother's crystal clear voice. There we encounter the heaven of our imagination, our wonderland, where anything was possible. We meet the Divine Infant, similar to us in body and shape. In the chants and hymns of the Church's great singers, the Lord's Nativity is like a chalice full of precious myrrh, which scented the contents of the discourse with the perfume of the chosen words, with the elevation of our reasoning, with the talent of rhyming, with the adornments of our speech and with deep feelings. It bore fruit: verses, hymns, and it is a driving force. It has commanded praises and unequalled glorification"

At other times Firmilian is capable of generating in the audience the ability to visualize countless images and 2,000-year old events, still so real before our eyes: "We celebrate today the Nativity of our Savior Jesus Christ. The torrent of worries freezes for a few moments. We await near the altars and in our homes. We renew our thoughts and feelings. The light of joy engulfs us like the gentle dusk. We become kinder, friendlier. Our inner warmth is released of awkwardness. Our eyes are livelier, and our face features are softened. It is like a transformation that astounds us, like innocence we keep going back to. The miracle of transformation derives from the mystery of this celebration. God's face reveals itself more clearly within us. His Son clothes himself in our flesh. The ascent of our soul's redemption begins. It lays the foundation of our salvation. It fills us with grace and truth. It becomes a model and an example. It changes the sorrow of death into a chant of victory; our fall into glory; eternal penitence, for eternal happiness"16. Or: "It is the celebration of God's descent into history. It is the beginning of His Son's work to raise our nation from death to life. This work began with His Birth from a Pure Virgin. It began in the humblest way possible: in a stable, on a layer of hay. It began in the most subdued way: a godly baby born in a cave" 17 .

\footnotetext{
${ }^{14}$ Pr. conf. dr. Miron Erdei, Opera omiletică a episcopului Roman Ciorogariu (Homiletic Work of the Bishop Roman Ciorogariu), Publishing House of the University of Oradea, 2012, p. 84

${ }^{15}$ Mitrop. Firmilian Marin, Pastorală la Nașterea Domnului (Pastoral Letter on the Occasion of the Lord's Birth), Craiova, 1966, p. 3

${ }^{16}$ Mitrop. Firmilian Marin, Pastorală la Nașterea Domnului ((Pastoral Letter on the Occasion of the Lord's Birth), Craiova, 1952, p. 3

${ }^{17}$ Mitrop. Firmilian Marin, Pastorală la Nașterea Domnului (Pastoral Letter on the Occasion of the Lord's Birth), Craiova, 1955, p. 3
} 
In the body of the sermon we find an amazing rationale governing the demonstration of the dogmatic and moral truth. There is a deep psychological analysis and a rigorous hierarchical classification of the arguments supporting the truth. As a general rule, the author starts from the known to the unknown elements, from the material to the abstract, and succeeds wonderfully in illustrating the abstract truths with examples from people's ordinary life. The Scripture texts are explained with quotations. A truth of faith is demonstrated through and corroborated with another truth of faith. The metropolitan bishop skillfully uses the technique or method of association, the discourse thus becoming a conversation between a parent and his children: "We then lost everything, having left in us only the unextinguished sparkle of our soul. We remained however with the precious promise of salvation, through the loving mercy of the Father and the humble obedience of the Son, according to the unwavering plan of the "eternal mystery". This is where the righteous people of old times drew their hope, this is where the confirmation of the prophets sprung from. The full redemptive work of Christ - the Messiah revealed itself to them in the mirror of faith and from them we too learned the signs of recognition. We especially think about those related to his Nativity. It is through them that we learned, for example, about: the Savior's people, the Birth from the Virgin, the time and circumstances of the Birth, His Holy Name, the magi's worship, the slaughter of the innocents. These prophets, enlightened by the Spirit, read as if from a book about the Savior's life. Thus, they rejoiced, knowing that he was a great prophet, like Moses, a high priest as Melchizedek and a glorified emperor in David's Zion. But they also saw His suffering and they were frightened. However, they found comfort in the hope and awaited for Him with unwavering faith, as in a long wake. Let us not forget, however, the difference between the solace of those of the old and our own. They rejoiced having only the benevolent promise and the signs; we have the Son's Incarnation and all fulfillments. They had the expectation, we - the glorification of angels and the evangelical grace. As in the ancient times, we find comfort in the same hope for the kindness and love of God-The Father. We hope that the Son will intercede for us, He Who, taking on a Human Body, restored to the human being not only the light of God's image within us, but also our likeness to Him, the possibility of sharing God's love and eternal life, knowing from Him that $<<$ God did not send His Son into the world to punish the world, but to save it through Him $>$ (John 3, 17). We had dug the unfathomable abyss of sin; Jesus laid at our feet the bridge of forgiveness. We drowned ourselves in the depths of disobedience towards God, and of slaughter; He lifted us into the light of discipleship. We had made ourselves into slaves, subjecting ourselves to lust; when $<<$ the time came $>>$, He made us $<<$ sons and heirs through God's grace $>>($ Galatians 4,4$) ", 18$.

The themes are varied, as were the aspects approached by the Metropolitan Firmilian. Thus, we find topics referring to anthropology, resurrection, God's love for people, the preservation of the Orthodox faith, and also subjects through which the worthy hierarch guides the religious and moral life of the Christians, by referring to life lived by abiding by the Savior's commandments and giving up sins, as well as habits that are morally and socially harmful. Taking into consideration the contents, we identify the main aspects present: the dogmatic and missionary, the social and moral and the pastoral.

As for the source of the sermons, the author uses as primary source the Holy Scripture, without neglecting the Holy Fathers, and sometimes we find illustrative

\footnotetext{
18 Mitrop. Firmilian Marin, "Pastorală la Sfintele Sărbători ale Naşterii Domnului" ("Pastoral Letter on the Occasion of the Sacred Holidays of the Lord's Birth"), in Mitropolia Olteniei (The Metropolitan Bishopric of Oltenia) nr. 11-12(1968), p. 882
} 
digressions. Benefitting from his rich knowledge in biblical and exegetic theology, the metropolitan father imbued his pastorals with rich biblical references. The Scripture texts used are well selected and organically integrated in the body of the discourse, increasing in a lively and natural manner their substance and doctrine value. In the second part of the text we notice certain aspects that preachers from the communist period were forced, in a way, to include, namely references to the so-called social, economic, political issues, etc. representing priorities of those sad times. It is a well-known fact that between 1948-1989 all speeches presented in manuscript for printing were first censored by the Department of Cults and only when they met all the requirements did they obtain permission to be published in the theological journals.

However, the value of his pastoral letters is not diminished, being well developed, thoroughly researched theologically and especially biblically and patristically, lacking any apologetic character, addressing strictly theological topics. Generally, the author used an intelligent, encrypted language, the subtlety of which often escaped the poor intelligence of the omnipresent political police, but did not elude the clever understanding or good sense of the average Christian. The pastoral letters of Metropolitan Firmilian are remarkable particularly because of their concision. The text at times has only a few pages: but there is nothing there that does not serve a purpose, the word is employed carefully, the teaching evinces such integrity that was difficult to maintain in the circumstances of the atheist communist propaganda, conveyed through an extraordinary subtlety of the message ${ }^{19}$.

The ending comprises, most of the times, the author's exhortation that the teachings presented remain deeply imprinted in the souls and minds of the Christians and materialize in their everyday life: "Following Christ's example, who helped us make peace with God, we owe to him to live in understanding and perfect brotherly love with each other, supporting one another and bearing the burden of one another, as Paul, the Apostle of the nations said. A heart that is at peace with itself and brotherly mutual aid engenders not only love for the homeland, but also and especially love for our fellow people, one of the most persistent evangelical commandments and the one out of which great Paul made a glorifying hymn. The liberation of man and the righteous renewal of his spirit are the impulse to run towards the Kingdom of light, to be kind, to love one's fellow men and being. It means life's victory over death" 20 . Insofar as the volume Merinde pentru suflet (Food for the soul) is concerned, we have before us, in fact, a book that can be used as a model in writing sermons, providing material for delivering a speech, including the author's reflections grouped around a title that constitutes the central idea of these meditations. In this volume the author commits himself to explaining the sacred truths - perceiving the fact that most Christians are not fully aware of their meanings - and fulfills his task enthusiastically and diligently, as a seeder would sow and heartily await the seeds to bear fruit.

These meditations usually have an introduction announcing the topic developed further on in the body of the text, by resorting to stories, argumentations or illustrative digressions, followed by explaining the relevance of the topic for the needs of the audience, then ending with exhortations and moral advice. The references to the Holy Scripture are quite numerous, so are the paragraphs from the Holy Fathers, intended to support an idea presented by the author and strengthening his statements.

\footnotetext{
${ }^{19}$ Pr. lect. dr. Adrian Ivan, "Considerații omiletice" ("Homiletic Considerations"), p. 182

20 Mitrop. Firmilian Marin, "Pastorală Învierea Domnului" ("Pastoral Letter on the Occasion of The Resurrection of the Lord"), in Mitropolia Olteniei (Metropolitan Bishopric of Oltenia) 3-4(1965), p. 274-275
} 
With regard to the style used, the Metropolitan Bishop proves himself to be an excellent master of the art of illustration, managing to avoid useless abstractions and guiding himself at all times according to the principle of Paul who says: "Yet in the church I would rather speak five words with my understanding, that by my voice I might teach others also, than ten thousand words in an unknown tongue" (I Corinthians 14, 19).

Recognizing the value of a constructive example instead of the countless abstract teachings, the author selects the illustrations with care, from varied fields, including the Bible and the Lives of Saints, lay history, people's everyday life. The parenetic side of the discourses of Metropolitan Firmilian is artfully highlighted by the use of the parable. In this sense, the parable brings a lot of light in the parenetic discourse thus rescuing it from a moralizing linearity. With Metropolitan Firmilian, we find more. Here the parable is closer to actual events than to the imaginary ones, and for this reason the great hierarch does not seek the ultimate conclusion, putting aside the epic significance, not even formulating it, but rather leaving it open in the audience's mind, whom he invites to reflect, to participate. The effect is that it allows the audience to interfere, to act, to protect the fair judgment and teaching of the Church. Thus, the parable also has an ironical undertone, there being a wise irony, in the writings and speeches of Metropolitan Firmilian ${ }^{21}$. In this respect, the following example is illustrative: "We had returned from the memorial of a neighbor. Noodles with geese, rice and pork. In addition some cheese pie. Food like the one you find in the countryside, abundant, so that people get up from the table satisfied. Wine and brandy at will. And at the end, white pretzels, baked in the oven. While talking with my folk, I was wondering: - Where did Lache get all that money to spend on this dinner? On a regular day, he can barely make ends meet. And now, food and drinks in quantities that would surpass the possibilities of a rich farmer. - He gets it by stealing, my father said. He sleeps well. Then, after night falls, he sets off through people's gardens looking for plums, hay, corn or beans, or wood from the village forest. So he is not one in need. On the contrary. He's got more than he can use. - Oh, goodness! Can this be possible? Theft and almsgiving go together? Well, son, an old woman assures me. They might not go together. But at least he is commemorating his mother. For this, God will forgive him" ${ }^{, 2}$. The style of the speeches included in the volume mentioned above is a simple one, with sentences that are not very long, with stories about the lives of saints, with quotes from the Holy Parents, having special impact on the audience because of the warmth and truth with which the lives and deeds of the saints are presented. The author describes in detail the life, the actions, the ordeals suffered for Christ, the humbleness and inner force that the mentioned saints proved throughout their erathly lives, so that they may later receive crowns of glory in the heaven, and especially the miracles worked by the saints with the help of God.

\section{CONCLUDING REMARKS}

In this study we intended to accomplish a synthesis of the work of this significant scholar and servant of the Romanian Orthodox Church, presenting both testimonies referring to his missionary and pastoral activity as well as comments on his rich contribution to the development of the homiletic genres, whether we are speaking about pastoral letters, theme sermons, panegyrics or pareneses. At the same time, the study aims to demonstrate, with examples and commentaries on these aspects, the original contribution of the Metropolitan Firmilian to the development of the homiletic literature, and for this reason he shall be

${ }^{21}$ Pr. lect. dr. Adrian Ivan, "Considerații omiletice" ("Homiletic considerations"), p. 180

${ }^{22}$ Mitrop. Firmilian Marin, Merinde (Food), p. 45 
remembered as a brilliant author in this genre. It is a vision that cannot be mistaken, a vision on the manner in which all these types of speeches are built, so that they convey not only rich ideas and edifying teachings, but also noble and redeeming feelings and emotions. Far from having exhausted the modalities of highlighting the value of the work of Metropolitan Bishop Firmilian, this work allows for other types of approaches to this abundant homiletic material, for example from the perspective of the frequency of certain topics in respect of others, or the structuring strategies of the discourses that differ from one stage to the other, depending on the daily reality. These aspects, as well as a possible and more thorough comparative research, with reference to several authors of homiletic literature may constitute various perspectives for future approaches of the matters that can be found in the work of the Metropolitan Firmilian, educated scholar and preacher.

\section{BIBLIOGRAPHY:}

[1] Anania, Bartolomeu, "Cuvânt înainte" ("Foreword") to Lect. dr. Ioan Toader, Metode noi în practica omiletică (New methods in the homiletic practice), Arhidiecezana, Cluj, 1997.

[2] Anania, Bartolomeu,"Prefață" ("Foreword"), in Firmilian Marin, Merinde pentru suflet (Food for the soul), Publishing House of the Metropolitan Bishopric of Oltenia, Craiova, 2004.

[3] Beldiman, Nicușor, Slujirea omiletică a mitropolitului Firmilian Marin (Homiletic Ministry of the Metropolitan Bishop Firmilian Marin), Publishing House of the University of Bucharest, 2017.

[4] Belu, Dumitru, Curs de Omiletică (A course in Homiletics), dactil., f.a., Sibiu.

[5] Chilea, Sebastian, "Apostolatul liturgic al Î.P.S. Firmilian" ("Liturgical Apostolate of His Eminence Firmilian”), in Mitropolia Olteniei 5-8 (1970).

[6] Colectiv, Dicţionar de proverbe şi cugetări latine (Dictionary of Latin proverbs and sayings), Albatros Publishing House, Bucharest, 1976.

[7] Creţu, Vasile, "Comunicarea în predică" ("Communication in sermons"), in Ortodoxia 3-4 (2004).

[8] Erdei, Miron, Opera omiletică a episcopului Roman Ciorogariu (Homiletic Work of the Bishop Roman Ciorogariu), Publishing House of the University of Oradea, 2012

[9] Gordon, Vasile, "Poeta nascitur, orator fit. Vocaţia omiletică a Mitropolitului Antonie Plămădeală" ("Homiletic Calling of the Metropolitan Bishop Antonie Plamadeala"), in Studii Teologice 4 (2005).

[10] Gordon, Vasile, Introducere în Omiletică (Introduction to Homiletics), Publishing House of the University of Bucharest, Bucharest, 2001.

[11] Ivan, Adrian, "Consideraţii omiletice asupra vieții și activităţii mitropoliților Firmilian Marin și Nestor Vornicescu" ("Homiletic considerations on the life and activity of the metropolitan bishops Firmilian Marin and Nestor Vornicescu"), in the volume Teologie și slujire pastorală în viața și opera mitropoliților Firmilian Marin și Nestor Vornicescu (Theology and pastoral service in the life and work of metropolitan bishops Firmilian Marin and Nestor Vornicescu), Publishing House of the Metropolitan Bishopric of Oltenia /Craiova, Editura Cetatea de Scaun/Târgoviște, 2014.

[12] Marin, Firmilian, "Pastorală Învierea Domnului" ("Pastoral Letter on the Occasion of The Resurrection of the Lord"), in Mitropolia Olteniei (Metropolitan Bishopric of Oltenia) 3-4(1965).

[13] Marin, Firmilian, "Pastorală la Sfintele Sărbători ale Naşterii Domnului" ("Pastoral Letter on the Occasion of the Sacred Holidays of the Lord's Birth"), in Mitropolia Olteniei (The Metropolitan Bishopric of Oltenia) nr. 11-12(1968).

[14] Marin, Firmilian, Pastorală la Nașterea Domnului ((Pastoral Letter on the Occasion of the Lord's Birth), Craiova, 1952.

[15] Marin, Firmilian, Pastorală la Nașterea Domnului (Pastoral Letter on the Occasion of the Lord's Birth), Craiova, 1966.

[16] Marin, Firmilian, Pastorală la Nașterea Domnului (Pastoral Letter on the Occasion of the Lord's Birth), Craiova, 1955.

[17] Neamțu, M., “Activitatea de propovăduitor a Î.P.S. Mitropolit Firmilian” ("The preaching activity of His Eminence Firmilian”), in Mitropolia Olteniei 5-8 (1970). 